\title{
Ethnopharmacy Study of Suku Anak Dalam (SAD) in Muara Kilis Village, Tengah Ilir, Tebo District, Jambi Province
}

\author{
Santi Perawati, Lili Andriani, Lia Anggresani, Eti Ardila \\ Sekolah Tinggi Ilmu Kesehatan Harapan Ibu Jambi, Indonesia \\ Email: santiperawati@stikes-hi.ac.id
}

\begin{abstract}
Background: Indonesia consists of various ethnics on each island, one of which is Suku Anak Dalam (SAD) precisely on Sumatra island of Jambi Province. Each ethnic group has a variety of natural and traditional remedies. This observation was conducted from November 2017 to February 2018 in Muara Kilis Village, Tengah Ilir District, Tebo District, Jambi Province.This research purpose to determined of various disease and know the various natural resources that are used as a treatmenton Suku Anak Dalam at Muara Kilis. Method: This research type is descriptive research using qualitative method and purposive sampling for sampling technique and open-ended interview with informant using voice recording media. Results: The disease are often experienced by Suku Anak Dalam among others fever, cough, asthma, measles, gastritis, hemorrhoids, stomachaches, and allergy. To treat the disease by utilizing natural resources like plants and animals. Part of the plants used among others, leaves, sap, and fruit, while for animal parts used are bile, urine, and blood. Processing methods are pounded, boiled, grated, and fried, while the use of these ingredients by eating, drinking, bathed, and applied directly on part of sickness skin. Conclusion: Based on the results that has been done there are 8 diseases that often occur and there are 5 kinds of plants and 4 animals from different genus and family that are used as traditional medicine in Suku Anak Dalam Muara Kilis Village.
\end{abstract}

Keywords: Ethnopharmacy, Suku Anak Dalam, Diseases, Natural Resources

\begin{abstract}
Abstrak, Latar belakang: Indonesia terdiri dari berbagai suku bangsa di masing-masing pulau, salah satunya adalah Suku Anak Dalam (SAD) tepatnya di Pulau Sumatra Provinsi Jambi. Setiap kelompok etnis memiliki beragam solusi alami dan tradisional. Pengamatan ini dilakukan dari November 2017 hingga Februari 2018 di Desa Muara Kilis, Kecamatan Tengah Ilir, Kabupaten Tebo, Provinsi Jambi. Penelitian ini bertujuan untuk mengetahui berbagai penyakit dan mengetahui berbagai sumber daya alam yang digunakan sebagai pengobatan pada Suku Anak Dalam di Muara Kilis. Metode: Jenis penelitian ini adalah penelitian deskriptif dengan menggunakan metode kualitatif dan purposive sampling untuk teknik pengambilan sampel dan wawancara terbuka dengan informan menggunakan media rekaman suara. Hasil: Penyakit yang sering dialami oleh Suku Anak Dalam antara lain demam, batuk, asma, campak, gastritis, wasir, sakit perut, dan alergi. Untuk mengobati penyakit dengan memanfaatkan sumber daya alam seperti tumbuhan dan hewan. Bagian tanaman yang digunakan antara lain daun, getah, dan buah, sedangkan untuk bagian hewan yang digunakan adalah empedu, air seni, dan darah. Metode pengolahannya ditumbuk, direbus, diparut, dan digoreng, sedangkan penggunaan ramuan ini dengan makan, minum, mandi, dan dioleskan langsung pada bagian kulit yang sakit. Kesimpulan: Berdasarkan hasil yang telah dilakukan ada 8 penyakit yang sering terjadi dan ada 5 jenis tanaman dan 4 hewan dari berbagai genus dan keluarga yang digunakan sebagai obat tradisional di Desa Suku Anak Dalam Muara Kilis.
\end{abstract}

Kata kunci: Etnofarmasi, Suku Anak Dalam, Penyakit, Sumber Daya Alam 


\section{INTRODUCTION}

On Sumatra island there are several large tribes that have traditional characteristics. The large tribes are Minangkabau, Malay, Aceh, and Batak. In addition, there are some minority tribes that inhabit some of the existing areas of Sumatra, namely large forest areas, around swamps, between large rivers, as well as on offshore islands. One of the minority tribe is Suku Anak Dalam (SAD) or commonly referred as Orang Rimba[1].The SAD community is part of an isolated group of people living on the Sumatra island, precisely in Jambi Province. SAD including primitive tribes who alienate themselves to live to interact in the forest by utilizing natural resources. They live in a culture of hunting and gathering.

SAD attitude that tend to be primitive is caused by environmental factors where they live in the forest so they do not know civilization outside the forest so that their rituality is still assured of its authenticity.

One of the uniqueness of SAD is the life of those who move or known as "Melangun". SAD clothes just use a loincloth or kancut to cover his cock. The wire is from a Terap or Serdang bark. The SAD community is very aware of the customs that have long existed for generations, as well as the perception of sickness, health and various types of plants that are used as traditional medicine is formed through belief and empirical science.. The use of plants as a medicinal substance is one of the activities of various tribes or a group of people who live in the interior. Tradition of treatment of a society can not be separated from the local cultural linkage.

Utilization of the diversity of plants to treat a disease is no longer a new thing, because the people of Indonesia have long known plants that have medicinal properties as one of the efforts in tackling various health problems. Medicinal plants are all types of plants that are known to have good properties in helping maintain health and treatment of a disease. Medicinal plants are closely related to traditional medicine, since most medicinal plant uses are based on experience of use and laboratory testing has not been performed.

The ingredients of traditional medicines are plant material, animal, mineral materials, extract (galenic) preparations or mixtures of such substances which have been hereditary for treatment, and may be applied in accordance with the norms prevailing in the community.

In this study the authors will seek information related to traditional medicine, know how to use and part of the material used as a drug and is expected to provide information related to the data of medicinal plants utilized Suku Anak Dalam (SAD) in Muara Kilis Village, Central Ilir, Tebo district, which could then be developed for the discovery of new drugs, and as evidence recorded in efforts to guard and enrich local wisdom .

\section{METHOD}

\section{Time and Place of Study}

The research was conducted in November 2017 until February 2018 in Muara Kilis Village, Tengah Ilir, Tebo District, Jambi Province, Indonesia.

\section{Sample Selection}

Sample selection technique in this research is purposive sampling that is the technique of selecting informant with certain consideration, in this case people who are considered very familiar with treatment.

\section{Data Collection}

To obtain data, researchers conducted interviews, and documentation on the SAD Interviews conducted in open-ended interviews on people who are considered to know all about treatment on the Tribe or also called "Tumenggung".

\section{Interview}

Interviews are an early stage to get the desired data. Interview technique is done by using open-ended interview. Interviews were directed to informants who knew about treatment. Such interviews include natural resources that are used in relation to treatment, organs utilized, local names of natural resources related to medication, treatment methods and drug side effects and interactions that occur with regard to treatmen.

\section{Plant Materials}

The researchers collected medicinal plants in the field and prepared for identification. Plants were identified using standard Herbarium at Biology FMIPA Andalas University of Padang, West Sumatra, Padjajaran University and Bandung Institute of Technology. After identified researchers 
examined the plants used have notes of literature.

\section{RESULTS AND DISCUSSION Result}

Based on research of ethnopharmaceutical surveys that have been done on Suku Anak Dalam (SAD), in Muara Kilis Village, Tengah Ilir, Tebo District of Jambi Province using Purposive Sampling method for sample selection or informant, while in data collection using Open-ended Interview method. Interviews were conducted on 2 informants namely Mr. Apung as Tumenggung and Mr. Hazril as a Dukun in SAD Muara Kilis, Tengah Ilir. The results showed that the disease that often occurs in SAD area there are 8 diseases that are fever, cough, dysentery, abdominal pain, gastritis, itching, shortness of breath and measles. The treatment uses natural ingredients such as capo, pertumbuhan, ketepeng, jernang, beruang, labi-labi, ular tedung, pisang kapas, and babi. This is known from interviews with informants.Some natural sources only certain parts are used. Complete data can be seen in Table 1. Source of natural materials (Capo, Jernang and Pertumbuhan) used for the treatment of plant determinated at Herbarium Andalas University of Padang, West Sumatra, Padjajaran University and Bandung Institute of Technology.

Table 1 Natural resources used by SAD to treat some deseases in Muara Kilis Village, Tengah Ilir, Tebo District, Jambi Province.

\begin{tabular}{|c|c|c|c|c|c|c|}
\hline No. & Local name & Scientific name & Family & Efficacy & $\begin{array}{l}\text { Part of } \\
\text { material } \\
\text { that used }\end{array}$ & Processing \\
\hline 1. & Pertumbuhan & $\begin{array}{l}\text { Cayratia japonica } \\
\text { (Thunb.) Gagnep }\end{array}$ & Vitaceae & Fever & Leaf & $\begin{array}{l}\text { Pounded } \\
\text { orBathed }\end{array}$ \\
\hline 2. & Capo & $\begin{array}{l}\text { Blumea } \\
\text { balsamifera (L.) } \\
\text { DC. }\end{array}$ & Asteraceae & Cough & Leaf & Boiled \\
\hline 3. & $\begin{array}{l}\text { Jernang Kuau } \\
\text { dan kelukup }\end{array}$ & $\begin{array}{l}\text { Daemonorops } \\
\text { draco(Willd.) } \\
\text { Blume dan } \\
\text { Daemonorops sp. }\end{array}$ & Arecaceae & $\begin{array}{l}\text { Abdominal } \\
\text { pain, } \\
\text { Dysentery }\end{array}$ & $\begin{array}{l}\text { Sap } \\
\text { Sap }\end{array}$ & $\begin{array}{l}\text { Pounded } \\
\text { Pounded }\end{array}$ \\
\hline 4. & Pisang Kapas & $\begin{array}{l}\text { Musa paradisiaca } \\
\text { (L.) }\end{array}$ & Musaceae & Gastritis & Fruit & Grated \\
\hline 5. & Ketepeng & Cassia alata $\mathrm{L}$. & Fabaceae & Itchy skin & Leaf & Grated \\
\hline 6. & Ular Tedung & Naja sputatrix. & Elapidae & Itchy skin & Blood & $\begin{array}{l}\text { Applied } \\
\text { directly on } \\
\text { part of } \\
\text { sickness skin }\end{array}$ \\
\hline 7. & Beruang & $\begin{array}{l}\text { Helarctos } \\
\text { malayanus }\end{array}$ & Ursidae & $\begin{array}{l}\text { Shortness } \\
\text { of breath }\end{array}$ & Bile & Fried \\
\hline 8. & Labi-labi & $\begin{array}{l}\text { Dogania } \\
\text { subplana }\end{array}$ & Trionychidae & $\begin{array}{l}\text { Shortness } \\
\text { of breath }\end{array}$ & Bile & Fried \\
\hline 9. & Babi & Sus barbatus & Suidae & Measles & Urine & $\begin{array}{l}\text { Applied } \\
\text { directly on } \\
\text { part of } \\
\text { sickness skin }\end{array}$ \\
\hline
\end{tabular}

\section{Discussion}

This study was conducted on the SAD community in Muara Kilis Village, Central Ilir District, Tebo District, Jambi Province. The total population of SAD in Muara Kilis village, consisting of 50 heads of families. Most of SAD in Muara Kilis village have embraced Islam, although some still hold animism and magical beliefs. The tradition of moving around in SAD 
known as "Melangun" is still done, although some of them choose to live in that area.

Based on the results obtained from interviews with two informants SAD Muara Kilis village there are 8 diseases and sources of natural materials used SAD related treatment. Eight of the diseases include fever, cough, abdominal pain, dysentery, gastritis, itching, shortness of breath, and measles. While the source of natural ingredients related to treatment are capo, pertumbuhan, jernang, pisang kapas, ketepeng, ular tedung, beruang, labi-labi, and babi. These natural resources are in SAD area and in the forests around where they live. SAD use natural resources as a hereditary treatment from their ancestors.

Natural resource-related treatments are consumed 3 times a day for three days. The use of natural resources related to treatment can be given at all ages only the different doses. For children to taste, while for adults use half a glass to a glass of the herb. The use of drugs will be discontinued if the disease has healed, and if there is no change for 3 days, then the SAD community considers the drug used is not suitable and replace it with other treatment. The treatment has no side effects and most do not interact, only when abdominal pain or diarrhea should not consume chili or spicy foods that they think may aggravate the situation.

\section{Description of Treatment with Natural Resources}

1. Ketepeng (Cassia alata L.)

Ketepeng plant in SAD Muara Kilis village used as medicines such as itch, panu, scabies and ringworm. Processing by way of some ketepeng leaves that have been cleaned pounded together with tembako cap chicken until smooth, then add a little oil to eat then smeared. Meanwhile, the Batin Tribe in Kecamatan Tabir Merangin District of Jambi Province utilizes ketepeng plant as a medicinal itchy. Ketepeng is also used as an antiparasit, ringworm, scabies, tineaversicolor, eczema, malaria, constipation, inflamed skin inflammation, syphilis, herpes, influenza and bronchitis.

Ketepeng plant has the efficacy as an internal medicine (karoko) because it can relieve pain that comes suddenly, by way of stems and roots ketepeng china mixed with the end of the leaves of Imperata (Imperata cylindrical Beauv.) Then given enough water and then boiled until boil, then cooled and drink water as much as 1 glass every morning and evening. SukuAnakDalam In The Village Tabun District VII Koto Tebo District Jambi utilize leaves ketepeng for tineaversicolor relief.

Ketepeng contains flavonoid compounds, alkaloids, and steroids. The phytochemical screening of simplicia powder shows that the ketepeng leaf powder contains flavonoids, alkaloids, anthraquinones, saponins and tannins.

\section{Capo (Blumea balsamifera L. DC.)}

$\mathrm{SAD}$ community in Muara Kilis village capo leaves used as cough medicine, by way of boiled capo boiling, filtered and then cooled then drunk 3 times a day. Capo plants in the tribal community in the District of Tabir Merangin Province Jambi Province leaves used as a cleansing drug after giving birth.

While the community in Muara Bangkahulu District, Bengkulu City, capo leaves used as a fever medicine by way of capo leaf squeezed and taken water and then touched, and compressed in the head.In Kutai National Park, East Kalimantan capo leaves efficacious as an abdominal pain medication, astringent, cough medicine, fever, malaria, stomach pain, and intestinal worms.

The leaves contain chemistry of borneol camphor, cine flavonoids, and glycosides. The capo leaves contain essential oils of camphor, tannin, saponin, resin, and xanthocylyn as well as flavonoids. The capo leaf, known as the Sembung leaves, contains flavonoids, saponins, tannins, flavonols, and essential oils.

\section{Jernang (Daemonorops sp.) and (Daemonorops draco(Willd.) Blume)}

In the village of SAD Muara Kilis there are 2 types of jernang is jernangkuau and kelukup. Both of these jernang have the same function that is to treat abdominal pain, coughing blood, wounds, dysentery and after childbirth, by pounding the sap from the jernang fruit is then mixed with turmeric and mixed with a glass of water, filtered and then drunk. At the time of taking the drug should not consume food containing chili.

SAD lives semi-nomadic or moves from one place to another, but only temporarily. In the area of Bukit Dua Belas National Park, $\mathrm{SAD}$ is headed by Tumenggung as the main chairman for the treatment of plant diseases 
SAD Bukit Dua Belas Society, Sarolangun Jambi utilizes (Daemonorops draco (Willd) Blume) as a headache, wound, fever, and diarrhea medicine. The part used for medicine is sap. To heal the wound can be done by scratching the sap, then apply on the wound. Society considers that sap (Daemonorops draco (Willd) Blume) can stop bleeding.

Subdistrictpauh, Sarolangun regency, Jambi province red resin on jernang used as medicine (diarrhea, anti tumor, anti virus, anti microbial, stop bleeding) and as dye (cosmetics, ink, and hair dye)]. The main chemical components contained in plant jernang are ester and dracoresinotanol resins, benzoylacetic acid, flavonoids, tannins, saponins, steroids / triterpenoids.

Resin jernang (Daemonorops draco) is used to improve blood circulation, reduce pain, increase tissue regeneration, sprains, ulcers and control of bleeding. Jernang (Daemonorops draco (Willd.) Blume) contains flavonoids and triterpenoids.

\section{Pisang Kapas (Musa paradisiaca L.)}

Pisang kapas plant is one of the nutritious plants as medicine. Tribe Son In Muara Kilis utilize Pisang kapas as a gastritis drug, by means of young pisang kapas cleaned and shredded and added a little salt then immediately eaten. Pisang kapas has various properties known as laxatives or laksan so it can be used for the treatment of constipation.

Mange Tribe In North Taliabu Subdistrict, Taliabu Island Regency, North Maluku Province Pisang kapas known as fiaa can be utilized as a difficult drug by shoot new pisang kapas shoots cut, young leaves 1 strands kneaded. The water is drunk half a glass once a day.

Pisang kapas utritious as a diarrhea drug, cotton bananas contain various nutrients, namely carbohydrates, proteins, fats, pectin, phenol content, pigments, vitamins, minerals and have antibacterial activity. Pisang kapas also contain saponin.

\section{Beruang (Helarctos malayanus)}

Bears are animals that can be used as traditional medicine. SAD Village Muara Kilis bear used as a drug shortness of breath, processing by way of fossil bear is fried then eaten.

While in Betung Kerihun National Park, West Kalimantan Indonesia of the 19 species of mammals that are used as medicine, bears are the most widely used by the people around the park area. People believe in bear bile as a remedy for deep wounds from fractures, sprains and minor accidents.

\section{Babi (Sus barbatus)}

Pigs are animals that are also used by SAD in the village of Muara kilis as traditional medicine. Part of which is used only urine alone, the animal urine is used as a measles medicine by applying urine mixed with vegetable oil to the body of measles disease. In Vietnam the pig bile from Sus domesticus species is believed to cure cough. One of the mammals used to treat human diseases in Gendewuha and Kumeraaftit kebeles from worms metema is pigs. Meat and blood animals are used as leprosy drugs, by consuming blood and meat in the form of stew.

\section{Ular Tedung (Naja sputatrix.)}

SAD at Muara Kilis also utilizes snakes related to the treatment of snakes or cobras. Used for disease tinea versicolor, scabies and ringworm, by applying the blood of the snake to the body of the disease.

Cobra or cobra snake has the property to cure allergies and skin-related diseases such as scabies, eczema. The people of Central Java take advantage of cobras or snakes as a cure for cancer, skin diseases (itching, eczema, allergies), respiratory illness, low blood pressure, liver, stroke, and increase stamina. At Bogor, West Java cobra snake or snake besides being used as a skin diseases medicine (itching) is also used to prevent eye fatigue, neutralize toxins in the body, increase stamina and sexual arousal.

\section{Labi-labi (Dogania subplana)}

The SAD community in Muara Kilis village bile Labi-labi is efficacious as a medication for shortness of breath, fried and then eaten. Dayak Kanayant people in Babane Village bile labi-labi can treat asthma and 
malaria disease. The way the process is very simple is to drink direct bile with warm water. In West Sumatra all parts of the body except the internal organs of the labi-labi can cure impotence, premature ejaculation and prevent venereal disease (syphilis).

\section{Pertumbuhan (Cayratia japonica (Thunb.) Gagnep) \\ Pertumbuhan in SAD Muara Kilis} village is used as a fever medicine by leaf growth is pounded, then add one glass of water and then drunk. While in Kabanjahe, North Sumatera growth is exploited as a medicine for fractures and fever. The part used leaves.

\section{BIBLIOGRAPHY}

Takiddin, "Nilai-Nilai Kearifan Budaya Lokal Orang Rimba (Studi Pada Suku Minoritas Rimba di Kecamatan Air Hitam Provinsi Jambi)", vol. 1. Jambi: UIN Syarif Hidayatullah, 2014.

F. Israhmat, "Sistem Kepercayaan Suku Anak Dalam (Studi Kasus SAD Air Hitam, Kabupaten Sarolangun, Provinsi Jambi)," 2016.

D. Wurjanto and Z. Nurdin, "Sekilas Kehidupan Orang Rimba di DAS Batanghari. Jambi", 2010.

M. Moekti Wardoyo, R. Abdul Kodir, and Y. Iskandar, "Etnofarmasi dan Ulasan Bioprospektif Tumbuhan Obat Liar Dalam Pengobatan Tradisional Kampung Adat Cikondang, Kecamatan Pangalengan, Kabupaten Bandung, Jawa Barat," Farmaka, vol. 15, pp. 2644, 2014.

M. Rahayu, S. Sunarti, D. Sulistiarini, and S. Prawiroatmodjo, "Pemanfaatan Tumbuhan Obat secara Tradisional oleh Masyarakat Lokal di Pulau Wawonii , Sulawesi Tenggara,"biodi versitas, vol. 7, pp. 245-250, 2006.

S. Susiarti, "Pengetahuan dan Pemanfaatan Tumbuhan Obat Masyarakat Lokal di Pulau Seram, Maluku," Pros Sem Nas Masy Biodiv Indon, Vol. 1, Pp. 10831087, 2015.

BPOM, "Peraturan Kepala BPOM Tentang Persyaratan Mutu Obat Tradisional", Jakarta: BPOM RI, 2014.

Rahyuni, E. Yniati, and R. Pitopang, "Kajian Etnobotani Tumbuhan Ritual Suku Tajio Di Desa Kasimbar Kabupaten Parigi Moutong," J. Nat. Sci., vol. 2, no. 2, pp. 46-54, 2013.

W. Ode Irma Indrayaningsih, N. Ibrahim, and S. Anam, "Studi Etnofarmasi Tumbuhan Berkhasiat Obat Pada Suku Buton di Kecamatan Binongko, Kabupaten Wakatobi, Sulawesi Tenggara," J. Pharm., vol. 1, pp. 7984, 2015.

Hermin, N. Ibrahim, and A. Wahyu Nugrahani, "Kajian Etnofarmasi Etnik Bungku di Kecamatan Bungku Tengah Kabupaten Morrowali Provinsi Sulawesi Tengah," J. Pharm. Vol., vol. 2, pp. 76-82, 2016.

U. Cakilcioglu, Khatun S, Turkoglu I, Hayta S, "Ethnopharmacological survey of medicinal plants in Maden (ElazigTurkey)", Ethnopharmacol, 2011.

Wulandari, "Penggunaan Hak Memilih Suku Anak Dalam Muara Kilis jambi," vol. 2014, pp. 1-18, 2016.

Jalius and Muswita, "Eksplorasi Pengetahuan Lokal Tentang Tumbuhan Obat di Suku Batin, Jambi," Biospecies, vol. 6 No 1, pp. 28-37, 2013.

Jumiarni wa ode, Komalasari O,"Eksplorasi Jenis Dan Pemanfaatan Tumbuhan Obat Pada Masyarakat Suku Muna Di Permukiman Kota Wuna", 2017.

G. Indriati, "Etnobotani Tumbuhan Obat Yang Digunakan Suku Anak Dalam Tabun Kecamatan VII Koto Kabupaten Tebo Jambi," J. sainstek, vol. VI, no. 1, pp. 52-56, 2014.

Muharram, T. Sulastry, and O. E. Sesa, "Isolasi Dan Identifikasi Senyawa Metabolit Sekunder Ekstrak Metanol Daun Ketepeng Cina (Cassia alata Linn)," chemical, vol. 15 No 1, pp. 136-143, 2014.

R. Saputra, "Pengaruh Jenis Pelarut terhadap Jumlah Ekstrak Dan Daya Antifungi Daun Ketepeng Cina (Cassia alata L.) Terhadap Jamur Trychophyton sp.," 2014.

S. Lenny, "tudi Etnobotani Jenis- Jenis Tumbuhan Obat Yang Dimanfaatkan Oleh Masyarakat di Kec. Muara Bangka Hulu Kota Bengkulu Sebagai Sumber Belajar Biologi SMP", 2014.

Noorhidayah and K. Sidiyasa, "Keanekaragaman Tumbuhan Berkhasiat Obat Di Taman Nasional Kutai, Kalimantan Timur," J. Anal. Kebijak. Kehutan., vol. 2, No, pp. 115-128, 2005.

A. Isnawati, M. Raini, and S. Alegantina, 
"Standarisasi Simplisia Dan Ekstrak Etanol Daun Sembung (Blumea balsamifera (L)) Dari Tiga Tempat Tumbuh." 2006.

U. Ruhimat, "Daya Hambat Infusum Daun Sembung (Blumea balsamifera) Terhadap Pertumbuhan Bakteri Escherichia coli Dengan Metode Difusi Cakram," J. Kesehat. bakti tunas husada, vol. 13, 2015.

A. Eriadi, R. Uthia, and R. Novita, "Pengaruh Pemberian Ekstrak Etanol Daun Sembung (Blumea balsamifera L. DC.) Terhadap Kadar Glukosa Darah dan Histopatologi Pankreas Mencit Putih Jantan yang Diinduksi Aloksan," $J$. Farm. Higea, vol. 9, no. 2, 2017.

Perawati, S, "Traditional Plants Medicine Of Suku Anak Dalam Jambi," Ris. Inf. Kesehat., vol. 6, no. 2, pp. 5-10, 2017.

D. Mairida, Muhadiono, and I. Hilwan, "Ethnobotanical Study of Rattans on Suku Anak Dalam Community in Bukit Duabelas Nasional Park," Biosaintifika, vol. 8, no. 1, pp. 64-72, 2016.

R. Asra and F. Farid, "Budidaya Rotan Jernang Untuk Petani Karet Di Pauh," J. Karya Abdi Masy., vol. 1, pp. 80-84, 2017.

R. W. Sari, A. Hikmat, and Y. Santoso, "Pendugaan Hasil Produksi Jernang Rotan Daemonorops Didymophylla Becc," 2015.

R. Asra, Syamsuardi, Mansyurdin, and J. R. Witono, "Rasio Seks Jernang (Daemonorops draco (Wild.) Blume) Pada Populasi Alami Dan Budidaya Implikasi Untuk Produksi Biji," vol. 15, no. 1, pp. 1-9, 2012.

Otok K. Waluyo and G. Pasaribu, "Aktifitas Antioksidan Dan Antikoagulasi Resin Jernang," J. Penelit. Has. hutan, vol. 31, no. 4, pp. 306-315, 2013.

Yuniarti N, Maulawati rina nur, Pramono S, "Effect Of Water Soluble Fraction Of Cotton Banana (Musa paradisiaca L.) Ethanolic Extract On The Blood Glucose Levels In Vivo And Active Compounds Identification", Tradit Med. 2014.

Yusri la Usaha, euis F. S. Pangemanan, and M. T. Lasut, "Pemanfaatan Tumbuhan
Obat Oleh Suku Mange Di Kecamatan Taliabu Utara Kabupaten Pulau Taliabu Provinsi Maluku Utara," no. 1, 2016.

T. Larasati, W. Hardita, and I. Dewi, "Aktivitas Musa paradisiaca dalam Terapi Diare Akut pada," vol. 1, pp. 424-427, 2016.

Setya E. Rikomah and Elmitra, "Identifikasi Senyawa Saponin Ekstrak Etanol Pelepah Pisang Uli (Musa Paradisiaca L)," Scientia, Vol. 7, No. 1, 2017.

Y. Ae putra, B. Masy'ud, and M. Ulfah, "Keanekaragaman Satwa Berkhasiat Obat Di Taman Nasional Betung Kerihun, Kalimantan Barat Indonesia," no. 510, pp. 8-15, 2008.

Van ND, "Tap N An overview of the use of plants and animals in traditional medicine systemsin Vietnam", A Traffic Southeast Asia Report, 2008.

M. Belay, "Medicinal Use of Fauna in the Indigenous Medicine System of Gendewuha and Kumeraaftit Kebeles of Metema Woreda, North West Ethiopia", 2015;4(8):459-64.

S. Haryanto, "30 Jenis Hewan Penakluk Penyakit", Jakarta. Penebar Swadaya. 2005.

D. Kartikasari, "Keanekaragaman Jenis dan Nilai Ekonomi Satwa Liar Yang Digunakan Sebagai Obat Di Jawa Tengah. Bogor : Program Pascasarjana", Institut Pertanian Bogor, 2008.

Situngkir SVR. Perdagangan Ular dan Pemanfaatannya Secara Tradisional Di Wilayah Bogor. In press.2009.

Bengkayang, "Etnozoologi suku dayak kanayant di desa babane kabupaten bengkayang (.J Hutan Lestari", 2017.

R. Hamdani, D. H. Tjong, and H. Herwin, "Potensi Herpetofauna Dalam Pengobatan Tradisional Di Sumatra Barat," vol. 2, no. 2, pp. 110-117, 2013.

M. Silalahi, Nisyawati, eko baroto Walujo, J. Supriatna, and W. Mangunwardoyo, "The local knowledge of medicinal plants trader and diversity of medicinal plants in the Kabanjahe traditional market , North Sumatra , Indonesia," vol. 175, pp. 432-443, 2015. 